\section{Adarcias: An Almond x Peach Hybrid Rootstock}

\author{
M.A. Moreno and R. Cambra \\ Departamento de Pomologia, Estación Experimental de Aula Dei (Consejo \\ Superior de Investigaciones Científicas), Apartado 202, 50080 Zaragoza, \\ Spain
}

Additional index words. Prunus amygdalo-persica, propagation
Adarcias is an almond $\mathrm{x}$ peach hybrid [Prunus amygdalo-persica] developed at the Estación Experimental de Aula Dei,Zaragoza, Spain, for use as a rootstock for peach $[P$. persica (L.) Batsch]. Cambra (1990) has described a parallel almond $x$ peach hybrid, Adafuel.

Peach scions grafted on Adarcias grow well; trees are less vigorous than on GF 677 or Adafuel. Cropping efficiency is higher or similar to that of either of these other hybrids (Table 1) (Moreno et al., 1994a, 1994b). Adarcias maiden trees have a semivigorous and upright growth, compared to the spreading shape of GF 677.

This rootstock is easily propagated by hardwood cuttings (Table 2). In addition, it can be propagated by in vitro techniques (J.A. Marín, personal communication).

Adarcias adapts well to light and calcareous soils, but it requires good drainage.

Tests performed in the nursery have shown that Adarcias is resistant to Coryneum beijerinckii Oud. and Tranzschelia prunispinosae (Pers.) Diet.

\section{Origin}

Adarcias was selected from openly pollinated seedling populations. Starting in 1970, selection work was performed at Estación Experimental de Aula Dei. The clone was initially tested as Arbucias and was selected because it had good rooting ability (Table 2), less vigor, and a higher or similar productivity index than other almond $x$ peach hybrids when used as a rootstock (Cambra, 1979; Moreno et al., 1994a, 1994b) (Table 1).

Adarcias would be suitable for peach cultivars to avoid excessive vigor, to increase

Received for publication 20 Sept. 1993. Accepted for publication 4 Feb. 1994. The cost of publishing this paper was defrayed in part by the payment of page charges. Under postal regulations, this paper therefore must be hereby marked advertisement solely to indicate this fact. planting density when tree size needs to be controlled, or to reduce production costs.

\section{Compatibility}

Adarcias has shown good compatibility with 20 tested peach and nectarine cultivars. It also has been tested with almond $[P$. dulcis (Mill.) D.A. Webb]. This rootstock also is graft-compatible with Japanese plum ( $P$. salicina Lindl.) cultivars, although the range of cultivars tested is not extensive. The compatibility with European plum and prune ( $P$. domestica L.) cultivars depends on the grafted cultivar (Moreno et al., 1994c).

\section{Description}

One-year-old shoots are green in spring or summer and intensely red in winter. They usually bear one flower bud per node. Internodes are medium in length, and leaves are peach type, large, and pale green with wavy serrated margins. The mean length : width ratio of the leaf blade is $16: 6$, slightly lower than that of GF 677 (12: 4). Leaf petioles generally have more than two reniform nectaries and two short stipules. Leaf fall is intermediate. ers with 45 to 50 stamens and one pistil that remains low beneath the anthers. Fruit are intermediate between peach and almond, with a 27-g mean weight, a 39-mm length, and 35$\mathrm{mm}$ width. The epidermis is pubescent and orange-yellow. The stone is free and rounded, and the seed is bitter and dark-golden brown.

\section{Availability}

Almond $x$ peach hybrid Adarcias registration is in progress at the Instituto Nacional de Semillas y Plantas de Vivero, Ministry of Agriculture. Small amounts of rooted cuttings or budwood can be obtained from the Estación Experimental de Aula Dei. Adarcias is free of all known viruses (Cambra, 1981).

\section{Literature Cited}

Cambra, R. 1979. Selección de híbridos espontáneos de almendro $x$ melocotonero. Información Técnica Económica Agraria 10:49-55.

Cambra, R. 1981. Híbridos de almendro X melocotonero españoles. III Jornadas Nacionales de Hortofruticultura, Zaragoza, junio.

Cambra, R. 1990. 'Adafuel' an almond x peach hybrid rootstock. HortScience 25:584.

Moreno, M.A., M.C. Tabuenca, and R. Cambra. 1994a. Comportamiento de la variedad de melocotonero Loadel injertada sobre diversos híbridos almendro $x$ melocotonero en vías de selección. Anales de la Estación Experimental de Aula Dei. (In press.)

Moreno, M.A., M.C. Tabuenca, and R. Cambra 1994b. Comportamiento de la variedad Catherina injertada sobre diversos híbridos almendro $x$ melocotonero en vías de selección. Anales de la Estación Experimental de Aula Dei. (In press.)

Moreno, M.A., M.C. Tabuenca, and R. Cambra. 1994c. Incompatibilidad entre patrón e injerto. Variedades de ciruelo injertadas sobre híbridos almendro X melocotonero. Anales de la Estación Experimental de Aula Dei. (In press.)
Adarcias has showy, large, light-pink flow-

Table 1. Rootstock effects on trunk cross-sectional area (TCSA) and productivity index of 'Catherine' and 'Flavortop' for the first 10 years.

\begin{tabular}{|c|c|c|c|c|}
\hline \multirow[b]{2}{*}{ Rootstock } & \multicolumn{2}{|c|}{ Catherine } & \multicolumn{2}{|c|}{ Flavortop } \\
\hline & $\begin{array}{l}\text { TCSA } \\
\left(\mathrm{cm}^{2}\right)\end{array}$ & $\begin{array}{c}\text { Productivity } \\
\text { index } \\
\left(10 \mathrm{~kg} \cdot \mathrm{cm}^{-2}\right)\end{array}$ & $\begin{array}{l}\text { TCSA } \\
\left(\mathrm{cm}^{2}\right)\end{array}$ & $\begin{array}{c}\text { Productivity } \\
\text { index } \\
\left(10 \mathrm{~kg} \cdot \mathrm{cm}^{-2}\right)\end{array}$ \\
\hline Adarcias & $240 \mathrm{a}^{2}$ & $6.4 \mathrm{a}$ & $207 \mathrm{a}$ & $12.2 \mathrm{~b}$ \\
\hline Adafuel & $362 \mathrm{~b}$ & $5.2 \mathrm{a}$ & $380 \mathrm{c}$ & $9.2 \mathrm{a}$ \\
\hline GF 677 & $324 \mathrm{~b}$ & $5.8 \mathrm{a}$ & $280 \mathrm{~b}$ & $12.0 \mathrm{~b}$ \\
\hline
\end{tabular}

${ }^{\mathrm{z}}$ Mean separation within columns by Duncan's multiple range test at $P \leq 0.05$.

Table 2. Percent rooting of hardwood cuttings of Adarcias, Adafuel, and GF 677 treated with $4000 \mathrm{ppm}$ indolebutyric acid.

\begin{tabular}{lcccr}
\hline \hline & \multicolumn{4}{c}{ Year } \\
\cline { 2 - 4 } Rootstock & $1989-90$ & $1990-91$ & $1991-92$ & Mean \\
\hline Adarcias & 83 & 67 & 80 & 77 \\
Adafuel & 88 & 71 & 84 & 81 \\
GF 677 & 77 & 51 & 65 & 64 \\
\hline
\end{tabular}

